Jurnal Scripta Teologi dan Pelayanan Kontekstual
ISSN
ISSN
Http://ejournal.stte.ac.id
Vol.4, No.2, pp. 111-131, 2019

\title{
Keberdosaan Manusia Menurut Alkitab
}

Yanjumseby Yeverson Manafe ${ }^{c}$

STT Ebenhaezer Tanjung Enim, manafeseby2@gmaill.com

\section{INFO ARTIKEL}

Sejarah Artikel:

Diterima : 04 Nov 2019

Direvisi : 12 Nov 2019

Disetujui: 23 Nov 2019

Dipublikasi: 28 Nov

2019

Kata Kunci:

Keberdosaan,

Manusia, Alkitab.

Keywords:

keyword one, keyword two, keyword three.

\begin{abstract}
ABSTRAK
Setelah kejatuhan manusia ke dalam dosa sebagaimana diuraikan dalam kitab Kejadian 3:1-24, membuat semua manusia keturunan Adam dan hawa hidup dalam dosa. Kendatipun demikian masih ada banyak orang Kristen yang belum dapat memahami dengan pasti adanya dosa di dalam hidup mereka. Jika setiap orang kristen tidak tahu bahwa ada dosa dalam dirinya maka akan sulit sekali untuk menanganinya. Oleh sebab itu, setiap orang Kristen harus mengetahui dan menyadari hakikat dari manusia berdosa serta mau melepaskan diri dari belenggu dosa. Dan hal ini akan terwujud di dalam dan melalui Roh Kudus. Berkenaan dengan keberdosaan manusia maka dalam tulisan ini akan dibahas berturut-turut mengenai keberdosaan manusia, yaitu: definisi dosa, istilah-istilah dosa dalam Alkitab, asal dosa, aspek-aspek dosa, akibat dosa dan jalan keluar dari dosa.
\end{abstract}

\section{ABSTRACT}

After the fall of man into sin as described in Genesis 3: 1-24, made all humans descend from Adam and Eve live in sin. Nevertheless there are still many Christians who have not been able to understand with certainty the existence of $\sin$ in their lives. If every Christian does not know that there is $\sin$ in him it will be very difficult to handle it. Therefore, every Christian must know and realize the nature of sinful humans and want to break away from the bondage of sin. And this will be realized in and through the Holy Spirit. With regard to human sinfulness, this paper will be discussed in succession regarding human sinfulness, namely: the definition of sin, the terms of sin in the Bible, the origin of $\sin$, aspects of $\sin$, the consequences of $\sin$ and the way out of $\sin$.

\section{Pendahuluan}

Alkitab menyatakan semua manusia berdosa. Siapa pun dan apa pun warna kulit kita, tanpa terkecuali, "Tidak ada yang benar, seorang pun tidak" (Rm. 3:10), semua telah kehilangan kemuliaan Allah. Tidak ada seorang pun yang hidup dalam kesucian. Inilah keadaan manusia, rusak oleh dosa. Pemazmur menegaskan bahwa di antara yang hidup tidak seorang pun yang benar di hadapan Allah (Mzm. 143:2). Selanjutnya pemazmur menegaskan dengan mengatakan bahwa "Terhadap Engkau, terhadap Engkau sajalah aku telah berdosa dan melakukan apa yang Kau anggap jahat, .... Sesungguhnya dalam kesalahan aku diperanakkan, dalam dosa aku dikandung ibuku" 
(Mzm. 51:6-7). Menunjukkan bahwa setiap orang tidak dapat menghindari dari kenyataan sebagai orang berdosa, namun patut disyukuri karena Yesus berkata, "Aku datang bukan untuk memanggil orang benar, melainkan orang berdosa" (Mat. 9:13). Sesungguhnya keberdosaan manusia adalah fakta yang dicatat dalam Alkitab dimulai dari Kitab Kejadian. John MacArthur, menjelaskan demikian:

The remainder of Genesis is filled with evidence of humanity's downward spiral into utter moral degradation. Genesis 3 is the turning point. Before that, God looked at creation and pronounced everything "very good" (1:31), nut after Genesis 3, all human history has been colored by which is very bad. (And the only exception are examples of God's redemptive work; they are not examples of human nobility.) Genesis 4 record the first murder, a case of fratricide. Verse 19 contains the first mention of polygamy. Verse 23 tells of another act of murder. And from there the human race declines so grievously that by Genesis 6:5, "The Lord saw that the wickedness of man was great in the earth, and that every intention of the thoughts of heart was only evil continually. "So God destroyed the entire race, except for one family. Genesis also records the beginnings of such evil as homosexuality (19:1), incest (19:30-38), idolatry (31:30-35) rape (34:1-2), mass murder (34:25-29), harlotry (38:14-19), and numerous other forms of wickedness.

Manusia tidak mungkin kembali ke jalan benar atas usahanya sendiri, oleh karena itu Tuhan Yesus turun ke dunia ini, Dia mati menebus dosa-dosa manusia. Dengan darah-Nya Tuhan Yesus menebus manusia dari dosanya, dalam 2 Korintus 5:21 lebih tegas dikatakan bahwa Yesus yang tidak mengenal dosa, telah dibuat-Nya menjadi dosa karena kita, supaya kita di dalam Dia dibenarkan oleh Allah.

\section{Metode Penelitian}

Penelitian ini adalah penelitian kualitatif dengan pendekatan grammatical analysis. grammatical analysis adalah "the first stage of determining the inner cohesion of the text is to analyze the relationships entween the individual units or terms in the next".(Osbone;1991:19). Paradigma yang digunakan adalah paradigma naturalistik, yang pada hakikatnya merupakan suatu upaya untuk menemukan kebenaran atau untuk lebih membenarkan kebenaran.

Teknik pengumpulan data dalam penelitian ini dilakukan dengan pengamatan atau partisipasi langsung dan penelaahan dokumen. Dalam wawancara ini, peneliti menggunakan pedoman secara tertulis yang telah dipersiapkan sebelumnya yang berisi sejumlah pertanyaan yang akan digunakan.

\section{Hasil Dan Pembahasan \\ Definisi Dosa}

Istilah "dosa" dipergunakan dalam beragam istilah dalam Alkitab, baik itu di dalam Perjanjian Lama maupun Perjanjian Baru. Pemahaman akan setiap istilah tersebut akan sangat menolong dalam memahami hakikat dari dosa itu sendiri. Definisi sederhana dari dosa di Alkitab adalah "meleset dari sasaran". Sasaran itu merupakan tanda atau "norma" dari Hukum Allah. Hukum Allah menyatakan kebenaran-Nya dan merupakan standar tertinggi bagi perilaku manusia.

Dosa didefinisikan sebagai "pelanggaran terhadap hukum Allah yang diberikan kepada makhluk yang berakal budi". (Kej. 3, Hos. 6:7; Yes. 24:5 dengan hati dan perbuatan (Kej. 20:3, 17; Kej. 6:5). Definisi ini memiliki tiga dimensi yang penting. 
Pertama, dosa merupakan ketidakmauan untuk menaati, yaitu ketidaktaatan terhadap hukum Allah. Dosa ini adalah dosa tidak melakukan yang diperintahkan Allah. Kedua, dosa didefinisikan sebagai pelanggaran terhadap hukum Allah. Pelanggaran terhadap hukum berarti melanggar batas yang telah ditentukan. Ketiga, dosa merupakan tindakan yang dilakukan oleh makhluk yang berakal budi. Sebagai makhluk yang diciptakan menurut gambar Allah, manusia merupakan pribadi yang memiliki kebebasan moral, memiliki akal budi dan kehendak, maka manusia mampu untuk bertindak secara moral. Pada waktu manusia melakukan sesuatu yang ia tahu adalah salah, maka ia memilih untuk tidak menaati hukum Allah dan berdosa.

Pemahaman akan setiap istilah tersebut akan sangat menolong dalam memahami hakikat dari dosa itu sendiri, bahwa "dosa" bukan sekedar suatu istilah dalam doktrin melainkan sikap dan tindakan terhadap Allah, Sang Pencipta yang menjadi Bapa untuk semua manusia.

\section{Istilah-Istilah Dosa Dalam Alkitab}

Mengenal arti dan makna dosa sebagaimana yang dimaksudkan Alkitab, menolong untuk melangkah hati-hati di dalam kehidupan ini. Alkitab menggunakan beberapa istilah untuk dosa. Hal ini tidak mengherankan karena tema utama Alkitab adalah "pemberontakan manusia terhadap Allah dan respon Allah yang penuh anugerah".

Berikut adalah istilah atau kata-kata asli dalam Alkitab (Perjanjian Lama: Ibrani; Perjanjian Baru: Yunani) yang diterjemahkan dalam Alkitab bahasa Indonesia sebagai "dosa".

\section{Perjanjian Lama}

Dalam Perjanjian Lama cukup banyak istilah-istilah yang dipergunakan sehubungan dosa dalam kehidupan manusia yaitu khet, pesya, syagag, asyam, awon/avon, hatta/khattat.

\section{Khet}

Merupakan istilah yang seasal dengan khattat. Istilah ini diantaranya terdapat dalam kitab Mazmur 51:11 yang berbunyi, "Sembunyikanlah wajah-Mu terhadap dosa (khet) ku, hapuskanlah segala kesalahanku”.

\section{Pesya}

Kata ini mempunyai arti tindakan "memberontak", "melawan", "menentang". Dapat disimpulkan hal ini menyangkut tentang pemberontakan atau pelanggaran terhadap kehendak dan perintah Allah. Istilah ini diantaranya dapat ditemui di dalam kitab Kejadian 31:36; Amsal 28:13; Hosea 8:1. Dalam Kejadian 31:36 tertulis, "Lalu hati Yakub panas dan ia bertengkar dengan Laban. la berkata kepada Laban: 'Apakah kesalahanku (pesya) apakah dosaku, maka engkau memburu aku sehebat itu?"

Alkitab memakai istilah ketiga dalam bahasa Ibrani, yaitu kata Ibrani פשע - Pesya', pê'-syïn-'ayin, berasal dari kata kerja פשע - Pasya', "memberontak", "melanggar" atau semacam pelanggaran. Jadi, dosa dalam pengertian פשע - Pesya' adalah dosa yang berhubungan dengan pemberontakan, perlawanan, penentangan terhadap yang berotoritas, baik terhadap manusia maupun terhadap Allah. 
Pelanggaran berarti ada suatu batas yang sudah ditetapkan, tetapi manusia melewatinya atau sudah ada suatu standard namun bukan saja tidak bisa mencapai tetapi juga manusia mau melawan atau melanggar. Maka pengertian ini bersangkut paut dengan suatu pengetahuan yang jelas, ditambah dengan kemauan yang tidak mau taat. Saya tahu apa itu baik, tapi saya sengaja melawan. Saya tahu batas sudah di situ, tetapi saya sengaja mau melewatinya. Tahu batas dan tahu tidak baik, tapi sengaja melewati, itulah yang disebut "pesya".

Jadi di sini Alkitab melihat dosa dalam ketiga aspek yang besar. Pertama, tidak mencapai atau menyeleweng dari standard yang ditetapkan Allah. Kedua, merupakan suatu hal yang salah atau sesuatu yang tidak seharusnya dikerjakan, tapi justru kerjakan. Hal yang kemudian disadari sebagai satu kesalahan, sesuatu yang benar telah dilakukan. Ketiga, adalah suatu pelanggaran yang sengaja dari seseorang.

\section{Syagag}

Kata ini berarti dosa yang "tidak disengaja", karena tidak hati-hati, karena tidak sadar dan tanpa diketahui. Contoh penggunaannya adalah dalam Imamat 4:2, 13. Contoh penggunaan: "Katakanlah kepada orang Israel: Apabila seseorang tidak dengan sengaja berbuat dosa (syagag) dalam sesuatu hal yang dilarang TUHAN dan ia memang melakukan salah satu dari padanya (Im. 4:2).

\section{Asyam}

Kata ini artinya adalah melanggar, berbuat khilaf atau kesalahan (Im. 6:2, 5, 6; 7:17). Contoh penggunaan: "Apabila seseorang berbuat dosa (asyam) dan berubah setia terhadap TUHAN, dan memungkiri terhadap sesamanya barang yang dipercayakan kepadanya, atau barang yang diserahkan kepadanya atau barang yang dirampasnya, atau apabila ia telah melakukan pemerasan atas sesamanya", (Im. 6:2).

\section{Awon/Avon}

Kata benda (nomina) Ibrani 'Âvon, -âlef - vâv - nun, diterjemahkan oleh LAI dengan "hukuman", "kedurjanaan", "kesalahan", "dosa". Kata ini berasal dari kata kerja 'Âvah, yang artinya adalah "membengkokkan" yang lurus, "memutarbalikkan", "mengubah bentuk". Kata Âvon/Awon senantiasa dihubungkan dengan perbuatan jahat (sesat, menyeleweng, murtad, dst) yang dilakukan semasa hidup di dunia. Contoh penggunaan: "Tetapi keturunan yang keempat akan kembali ke sini, sebab sebelum itu kedurjanaan (awon) orang Amori itu belum genap" (Kej. 15:16). Sebagai kesimpulan, setidaknya ada enam kata dalam Alkitab bahasa Ibrani Perjanjian Lama yang diterjemahkan sebagai "dosa" dalam Alkitab bahasa Indonesia, atau "sin" dalam Alkitab yang berbahasa Inggris.

Istilah di dalam bahasa Ibrani yang dipakai untuk dosa adalah "avon". Kata Ibrani עון - 'Âvon, 'ayin-vâv-nûn sõfit, berasal dari kata kerja - 'Âvah, 'ayin-vâvhê', "melakukan kesalahan", "bersalah", secara konseptual bermakna "membengkokkan yang lurus". Kata ini lebih banyak diterjemahkan "kesalahan terhadap manusia ketimbang "dosa" terhadap Allah.

Jadi kata ini dipakai untuk menunjukkan suatu kesalahan "guilty" atau suatu hal yang mengakibatkan seseorang merasa patut dihukum. Istilah ini sulit diterjemahkan ke dalam bahasa Indonesia. Suatu perasaan di dalam diri seseorang yang menganggap diri cacat atau perasaan di dalam jiwa yang merasa diri kurang benar, sehingga selalu 
merasa mau menegur dirinya. Hal ini bersangkutpaut dengan fungsi hati nurani yang diberikan hanya kepada manusia saja.

Tidak ada binatang yang mempunyai 'guilty feeling', tidak ada binatang yang bisa menegur diri karena merasakan sesuatu hal yang tidak benar yang sudah diperbuatnya. Tetapi manusia tidak demikian, mempunyai perasaan berhutang atau perasaan bahwa ia patut dihukum. Perasaan sedemikian berdasarkan suatu pikiran dari apa yang sudah dikerjakan, yang kemudian sadar akan statusnya dalam keadaan patut dihukum.

\section{Hatta/Khattat}

Dosa dalam PL diterjemahkan dari istilah yang dipakai dalam bahasa Ibrani Kata benda (nomina) Ibrani חטאה - Khata'ah, khêt - têt - 'âlef - hê, atau Khatat, khêt - têt 'âlef - tâv, yang diterjemahkan "dosa", berasal dari kata kerja (verba) טטא - Khata', melakukan dosa, tidak mengenai, luput, gagal; ibarat seseorang memanah tetapi anak panahnya tidak kena pada sasaran. Secara konseptual bermakna "meleset dari sasaran atau jalan yang benar". Secara lebih tajam, istilah ini diartikan Stephen Tong, sebagai jatuh dan mengurangi standard dari Tuhan yang suci (falling short of the standard of God). Jadi sebenarnya Allah telah menetapkan suatu standard. Pada waktu manusia lepas, ia turun dari standard yang ditetapkan oleh Allah, itu disebut "hatta" (dosa), sehingga dalam hal ini istilah dosa harus dimengerti bukan dengan cara dunia dalam pengertian hukum. Waktu berbicara tentang hukum berarti secara tidak sadar mereka sudah menyetujui bahwa fakta dosa sudah ada di dalam dunia. Berdasarkan pengertian akan fakta dosa secara serius, maka agama mempunyai tempat dan akar yang cukup kuat dan tidak mungkin dapat dicabut oleh kebudayaan manapun.

Dalam pengertian hukum dunia, dosa yang merupakan suatu fakta adalah pelanggaran terhadap sesuatu yang sudah secara perjanjian bersama (konsensus) ditetapkan oleh ahli-ahli hukum agar menjadi patokan untuk mengatur hidup sosial dan etika dalam masyarakat. Jikalau ahli-ahli hukum sudah menyetujui secara konsensus lalu mencantumkan di dalam hukum suatu negara, maka apa yang dicantumkan itu menjadi standard negara itu. Barangsiapa berbuat sesuatu yang melanggar konsensus yang dicatat dalam hukum itu, disebut dosa. Di sinilah kelemahan dari semua hukum dari dunia ini yaitu mereka hanya sanggup melihat akibat dosa dan itu pun adalah aspek yang paling rendah yaitu kelakuan yang salah.

Sekali lagi, meskipun dalam hukum ditentukan perbedaan hukuman atas kesalahan berencana atau yang tidak berencana, tetapi tidak ada suatu hukum yang bisa langsung menghukum orang yang mempunyai niat atau rencana di dalam hati namun belum melakukan sesuatu di luar. Maksudnya, jikalau seseorang mempunyai hati yang ingin mencuri, tidak ada hukum di dunia yang boleh langsung memenjarakan dia, kecuali dia sudah melaksanakannya. Dengan demikian di seluruh dunia, pengertian hukum dan keadilan hanyalah dapat mengerti dosa di dalam hal yang superficial (yang tampak di permukaan). Dunia hanya mengerti dan menetapkan dosa berdasarkan sesuatu perbuatan yang dianggap melanggar suatu konsensus tentang hukum.

Tetapi Alkitab tidak demikian. Alkitab berkata dengan jelas, "yang membenci seseorang, sudah membunuh" (Mat. 5:21-22). Di sini etika Kristen adalah etika yang melampaui perbuatan yang nyata di dunia. Etika Kristen merupakan etika yang langsung ditujukan kepada motivasi seseorang secara terbuka di hadapan Tuhan. Allah sedemikian marah seperti api yang menyala-nyala. Allah yang menembus hati sanubari 
manusia dan tidak melihat perbuatan di luar, tetapi Dia melihat motivasi manusia di dalam hatinya.

Kebenaran Allah menuntut kepada keseluruhan hidup manusia, mulai dari motivasi di dalam, segala rencana di dalam, pikiran di dalam, mentalitas di dalam, sikap yang setengah di dalam setengah di luar, sampai perbuatan yang seluruhnya di luar. Semua ini dituntut oleh Tuhan. Menjadi seorang manusia berarti menjadi orang yang dicipta menurut peta dan teladan Allah dan dicipta supaya dia berdiri dan bertanggung jawab secara pribadi kepada Tuhan Allah. Tidak ada yang lain yang bisa menghalangi. Di hadapan Allah setiap orang harus mempertanggungjawabkan segala motivasi, pikiran, semua sikap mentalitas, semua sikap dan sifat pribadi, semua perkataan. Hal ini menjadikan kekristenan seperti apa yang dikatakan Kierkegaard bahwa menjadi orang Kristen terlalu sulit, karena Allah bukan menuntut hal-hal yang tampak di luar.

Hukum-hukum di dunia hanya bisa menunjukkan seseorang berdosa setelah menemukan dan membuktikan bahwa mereka sudah berbuat, mengaku, atau sudah mengekspresikan apa yang diinginkan di dalam perbuatan yang merugikan orang lain. Tetapi tidak demikian dengan kekristenan dan iman Kristen. Allah menuntut secara keseluruhan yaitu sampai ke dalam hati sanubari yang terdalam, sampai ke dalam motivasi sesorang di hadapan Tuhan dimana orang lain tidak melihat. Sesungguhnya menjadi orang Kristen memang tidak mudah, tapi bukan tidak mungkin.

Alkitab memakai istilah ini 580 kali di dalam Perjajian Lama. Istilah "hatta" merupakan suatu istilah yang begitu menyedihkan bagi Tuhan. Kekristenan menunjukkan suatu hal yang tidak ada pada agama lain, yaitu Allah telah menetapkan suatu standard bagi manusia, sehingga ia tidak bisa hidup secara sembarangan. Di dalam agama-agama yang lain, mereka mempunyai standard mereka sendiri. Mereka mempunyai tujuan mereka sendiri dan tujuan yang didasarkan pada diri mereka yang sudah jatuh ke dalam dosa, yang tidak mereka sadari. Mereka ingin mencapai suatu hidup yang tinggi yang suci. Namun bagaimanapun tingginya tujuan itu hanyalah merupakan hasil dari otak yang sudah jatuh di dalam dosa. Sedangkan waktu Allah mengatakan "hatta", berarti manusia sudah hidup lebih rendah daripada standard yang sudah ditetapkan oleh Allah sendiri. Dosa tidak boleh hanya dimengerti sebagai mencuri, berzinah, berjudi, main pelacur, atau mabuk-mabuk, itu memang tidak salah. Itu adalah akibat dari dosa, merupakan hal yang superfisial, sesuatu yang hanya ditunjukan di luar. Tuntutan Alkitab jauh lebih dalam dan lebih lengkap, secara totalitas daripada itu. Suatu standard telah ditetapkan Allah bagi manusia sebagai syarat atau kriteria tingkah laku dan moralitas manusia.

Jadi disini Alkitab melihat dosa dalam ketiga aspek yang besar. Pertama, tidak mencapai atau menyeleweng dari standard yang ditetapkan Allah. Kedua, merupakan suatu hal yang salah atau sesuatu yang tidak seharusnya dikerjakan, tapi justru dikerjakan. Hal yang kemudian disadari sebagai satu kesalahan, sesuatu yang benar telah dilakukan. Ketiga, adalah suatu pelanggaran yang sengaja dari seseorang.

\section{Perjanjian Baru}

Dalam Alkitab Perjanjian Baru juga ada banyak istilah yang dipakai untuk menunjukan dosa, berikut ini akan dibahas beberapa yang dianggap penting. 


\section{Adikia}

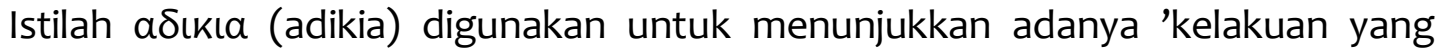
berlawanan dengan hukum yang berlaku', 'kejahatan' atau perbuatan yang tidak benar. Itu berarti berhubungan dengan perbuatan lahiriah atau dari luar, yang dinilai merupakan sesuatu perbuatan yang tidak benar sama seperti yang dikatakan oleh hukum-hukum dunia tentang orang bersalah. Di pengadilan ketika semua pemeriksaan sudah selesai, maka hakim akan memvonis, bahwa seseorang itu bersalah. Itulah "adikia", berarti seseorang sudah berbuat salah. Kata ini juga dipakai di 1 Yohanes 1:9; 1 Yohanes 5:17. Contoh penggunaan: "Semua kejahatan (adikia) adalah dosa, tetapi ada dosa yang tidak mendatangkan maut". (1 Yoh. 5:17).

Kejahatan adalah segala sesuatu yang bersifat merusak, menghambat, dan menghancurkan tujuan dan makna mula-mula Allah dalam mencipta semesta ini. N. T. Wright memberikan definisi tentang kejahatan demikian: "Evil is the force of anticreation, anti-life, the force which opposes and seeks to deface and destroy God's good world of space, time and matter, and above all God's image-bearing human creatures". Sesuatu yang anti-Allah! Kejahatan adalah segala sesuatu yang berupaya menjauhkan manusia dari rencana Allah yang menghidupkan.

Paling tidak ada empat pemikiran mendasar mengenai kejahatan. Pertama, kejahatan dapat didefinisikan sebagai absennya atau ketiadaan dari sesuatu yang baik. Kejahatan merupakan kerusakan atau devisiasi (penyimpangan) dari apa yang sebenarnya. Kejahatan ada sebagai kerusakan dari sesuatu yang baik. Kedua, kejahatan tidak memiliki esensi dari dirinya sendiri. Kejahatan tidak eksis secara sendirinya, ia ada di dalam sesuatu dan bukan di dalam dirinya sendiri. Misalnya, lubang itu riil, tapi hanya ada dalam sesuatu yang lain. Kita bisa katakan tidak adanya tanah sebagai sebuah lubang, tapi lubang tidak bisa dipisahkan dari tanah. Misalnya, kelapukan pada pohon terjadi karena adanya pohon. Tidak ada kelapukan jika tidak ada pohon. Kebusukan pada gigi hanya dapat terjadi selama gigi itu ada. Ketiga, kejahatan itu adalah sesuatu yang aktual, bukan ilusi. Walaupun kejahatan itu tidak eksis dari dirinya sendiri, tidak berarti bahwa kejahatan itu adalah sesuatu yang abstrak atau hanya khayalan belaka. Kejahatan itu nyata, dapat dilihat, dan dialami. Keempat, kejahatan dapat dikategorikan dalam dua bentuk, yaitu kejahatan moral dan kejahatan natural. Kejahatan moral adalah kejahatan yang dilakukan oleh agen atau pelakupelaku moral yang bebas. Contoh dari kejahatan moral ini adalah perang, kriminalitas, diskriminasi, perbudakan, pembantaian, dan lain-lain. Kejahatan natural adalah kejahatan yang tidak melibatkan kehendak dan tindakan manusia tetapi merupakan aspek alam yang bekerja melawan manusia. Contoh dari kejahatan natural ini adalah badai, tsunami, gempa bumi, banjir, gunung meletus, dan lain-lain. Kejahatan dalam bentuk moral maupun kejahatan dalam bentuk natural adalah kerusakan sesuatu yang baik dan memberi dampak yang negatif.

\section{Hamartia}

Istilah kedua dalam Perjanjian Baru adalah a dari sasaran yang dituju, kehilangan, meleset dari target atau sasaran yang ditetapkan

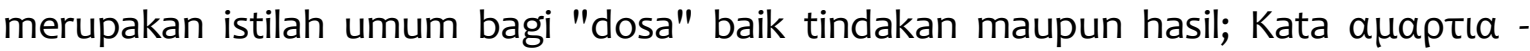
hamartia ini adalah istilah umum bagi kata "dosa" yang digunakan paling banyak dalam Perjanjian Baru Yunani, yaitu 174 kali. 71 kali diantaranya terdapat di dalam surat-surat Rasul Paulus. Kata ini bukan hanya menunjuk pada perbuatan dosa, tetapi juga 
keadaan hati dan pikiran yang jahat. Contoh penggunaan: "Karena semua orang telah berbuat dosa (hamartia) dan telah kehilangan kemuliaan Allah", (Rm. 3:23). Contoh lainnya: "la akan melahirkan anak laki-laki dan engkau akan menamakan Dia Yesus, karena Dialah yang akan menyelamatkan umat-Nya dari dosa (hamartia) mereka" (Mat. 1:21). Searah dengan itu, Stephen Tong mengatakan: Jika saya melepaskan satu anak panah menuju pada satu sasaran yang sudah jelas, yaitu lingkaran tertentu yang harus dicapai, tetapi anak panah itu jatuh satu meter sebelum sasaran itu, maka itu disebut "hamartia". Sekali lagi saya berusaha untuk melepaskan panah, tetapi kini bukan tidak sampai, tapi terus lewat jauh dari target yang ditetapkan, itupun disebut "hamartia". Atau ketiga kalinya saya melepaskan panah, panah itu terbang menuju sasaran, namun menancap $2 \mathrm{~cm}$ dari sasaran, berhenti di pinggir target itu, itu tetap artinya "hamartia".

Jadi di sini tidak peduli kurang berapa meter atau lebih berapa centimeter atau meleset hanya beberapa milimeter, itu semua dianggap sama. Hanya mereka yang betul-betul sesuai dengan sasaran asli, itu yang dianggap benar. Yang lain semua dianggap "hamartia".

\section{Parabasis}

Kata ini berasal dari kata kerja "Parabaino" yang maknanya adalah "melanggar". Secara konseptual berarti berjalan melewati garis, seperti para murid Yesus dituduh "melanggar" adat istiadat nenek moyang mereka, dan ungkapan "melangkah keluar" dari ajaran Yesus dalam 2 Yohanes 1: 9.

Jadi, "parabasis" berarti "pelanggaran" atau "menyimpang dari yang seharusnya”. Dalam Perjanjian Baru, kata ini selalu dipakai dalam hal pelanggaran hukum yang pasti (Rm. 4:15; 2 Ptr. 2:16). Hukum-hukum Allah menuntut ketaatan manusia, dan jika manusia tidak mentaatinya berarti ia adalah "pelanggar hukum" dan berdosa sehingga murka Allah akan menimpanya (Rm. 4:15). Contoh penggunaan: "Lagipula bukan Adam yang tergoda, melainkan perempuan itulah yang tergoda dan jatuh ke dalam dosa (parabasis)" (1 Tim. 2:14).

\section{Anomia}

Kata ini berasal dari kata sifat "anomos" yaitu partikel negatif A dan kata benda "nomos" (hukum). Jadi, anomia adalah "suatu kondisi tanpa hukum karena mengabaikannya/tidak memperdulikan hukum/tidak mentaati hukum”. Contoh penggunaan: "Setiap orang yang berbuat dosa, melanggar juga hukum Allah (anomia), sebab dosa ialah 'pelanggaran hukum Allah' (anomia)” (1 Yoh. 3:4).

\section{Asebeia}

Kata ini memiliki makna atau berbicara tentang kefasikan dan tidak mengenal Allah (Tit. 2:12).

\section{Paraptoma}

Kata ini memiliki makna kesalahan, tidak berdiri teguh pada saat harus teguh, tidak sampai kepada yang seharusnya, pelanggaran secara sengaja (Mat. 6: 14-15, Rm. 4: 24; Gal. 6:1; Yak. 5:16). 


\section{Agnoema}

Artinya tidak berpengetahuan, tidak berpengertian. Contoh penggunaan: "tetapi ke dalam kemah yang kedua hanya Imam Besar saja yang masuk sekali setahun, dan harus dengan darah yang ia persembahkan karena dirinya sendiri dan karena 'pelanggaran-pelanggaran', yang dibuat oleh umatnya 'dengan tidak sadar' (agnoema)" (Ibr. 9:7).

Dari ke 13 istilah, enam dalam bahasa Ibrani, di Perjanjian Lama dan tujuh dalam bahasa Yunani di Perjanjian Baru, terlihat suatu gambaran yang jelas bahwa manusia dicipta bukan untuk kebebasan yang tanpa arah, tetapi manusia diciptakan dengan standard yang sudah ditetapkan.

Selain itu, dosa dapat juga didefinisikan sebagai pemberontakan secara aktif terhadap Allah Pencipta yang menyebabkan manusia tidak taat, melanggar hukum Allah, dan menyimpang dari tujuan Allah yang menciptakannya. Dosa selalu berkontradiksi dengan kekudusan Allah sehingga tidak dapat dipandang sepele, sebaliknya harus dipandang serius.

Dengan demikian, dosa bukanlah sesuatu yang timbul dari sifat kebinatangan manusia karena manusia diciptakan berbeda secara esensial dengan binatang. Dosa juga bukan nafsu fisikal manusia semata-mata. Dosa adalah pemberontakan terhadap Allah dan setelah kejatuhan Adam dalam dosa, dosa melekat pada setiap manusia keturunannya seperti yang diungkapkan oleh Daud, "Sesungguhnya, ... dalam dosa aku dikandung ibuku" (Mzm. 51:7).

Jadi penelaahan terhadap penggunaan kata-kata itu dan bagaimana cara Alkitab memakainya untuk menunjukkan bahwa dosa, sehingga tidaklah diragukan lagi akan karakter etis dosa tersebut. Sesungguhnya dosa itu bukanlah seperti bencana yang melanda manusia tanpa peringatan, meracuni hidup manusia dan bahkan menghancurkan kebahagiaannya, tetapi merupakan suatu tindakan kejahatan yang dengan sengaja telah dipilih oleh manusia dan yang akibatnya membawa kesusahan dan malapetaka bagi manusia itu sendiri.

Jadi, dosa adalah akibat dari suatu pilihan bebas tapi jahat dari manusia, dan bukanlah sesuatu yang pasif seperti kelemahan, suatu kesalahan atau suatu ketidaksempurnaan yang akhirnya tidak dapat dituntut pertanggungjawaban, tetapi pada dasarnya adalah merupakan suatu permusuhan dengan Allah dan hukum-Nya.

\section{Asalnya Dosa}

Peristiwa kejatuhan Adam dan Hawa ke dalam dosa saat berada di Taman Eden setelah dipengaruhi oleh ular, adalah bukan asalnya melainkan kisah masuknya dosa ke dalam dunia. Kisah yang dimulai oleh Kitab Kejadian yang mengajarkan bahwa Allah menciptakan makhluk yang bernama "manusia" (Kej. 1:26-28). Manusia adalah ciptaan yang diciptakan "segambar" dengan Allah. Salah satu makna dari "segambar" dengan Allah adalah bahwa manusia itu diberikan "akal budi", sesuatu yang membedakannya dari hewan, tumbuhan dsb. Dengan akal budi itu, manusia mempunyai pikiran atau kehendak bebasnya.

Penggunaan "kehendak bebas" inilah yang tercetak tebal dalam kisah di Taman Eden. Allah memberikan Firman agar Adam dan Hawa tidak memakan buah dari "Pohon Pengetahuan tentang yang baik dan yang jahat". Buah dari pohon-pohon lainnya boleh mereka makan. Hanya buah dari pohon itu saja yang tidak boleh dimakan, karena bisa mengakibatkan "kematian" (Kej. 2:15-17). Tidak diceritakan 
berapa lama keduanya menghuni Taman Eden dan menikmati segala yang terindah. Sampai suatu hari, ular datang dan membujuk Hawa untuk memakan buah dari Pohon Pengetahuan tentang yang baik dan yang jahat tersebut. Singkat cerita, keduanya lalu memakan buah dari pohon tersebut. Tindakan mereka mengakibatkan keduanya menjadi "telanjang", hal yang menunjuk pada kehilangan kemuliaan Allah (Rm. 3:23) dan mengalami kematian pada akhirnya.

Orang lalu menghubungkan peristiwa itu dengan Allah sehingga timbul pemikiran-pemikiran yang keliru. Misalnya, apakah Allah tidak mengetahui tindakan ular yang menghampiri Hawa? Apakah Allah tidak melihat percakapan antara Hawa dan ular tersebut? Apakah Allah tidak tahu ketika Hawa memakan buah itu? Jawabannya ialah, tentu Allah mengetahuinya, karena Dia Maha Tahu. Bila demikian, mengapa Allah membiarkan Adam dan Hawa memakan buah itu dan akhirnya jatuh ke dalam dosa? Jawabannya karena Allah tidak menciptakan "robot" yang telah terprogram. Allah telah menciptakan "manusia” yang mempunyai akal budi. Makhluk yang bisa memutuskan untuk mengasihi dan taat kepada-Nya ataupun memutuskan untuk tidak mengasihi dan tidak menaati-Nya. Dia memberikan "kebebasan" kepada Adam dan Hawa untuk memilih menaati Dia atau tidak. Pilihan Adam dan Hawa ternyata adalah "tidak taat" dan menyimpang dari rencana kebaikan Tuhan atas mereka.

Jadi, jelaslah bahwa sesungguhnya Allah tidak memberikan kesempatan pada dosa di Taman Eden, tetapi memberikan kesempatan pada manusia untuk "memilih" menjadi taat atau tidak taat kepada-Nya. Dan ketika manusia memilih untuk tidak taat, maka dosa masuk ke dalam dunia. Salah satu arti dari dosa adalah ketidaktaatan atau menyimpang dari perintah Tuhan.

Hegel pernah mengatakan, "Kejahatan merupakan suatu langkah yang perlu di dalam perkembangan sejarah". Kalimat ini bisa berarti bahwa Allahlah yang menghendaki dosa itu ada dalam sejarah manusia sehingga la dapat menunjukkan kebaikan-Nya dan manusia dapat belajar dari kesalahannya. Atau dengan kata lain, dosa berasal dari kekekalan. Pandangan ini keliru karena hanya Allahlah yang berasal dari kekekalan, dan di dalam kekudusan-Nya, tidak mungkin dosa memperoleh tempat. Jika dosa adalah atas kehendak dan prakarsa Allah, maka pengusiran manusia dari kekudusan Allah merupakan sandiwara terbaik yang pernah ada dalam sejarah manusia. Hal ini dapat berarti bahwa Allah itu kudus sekaligus berdosa. Jika demikian, Allah adalah penipu sebab la pernah berkata, "Kuduslah kamu, sebab Aku, Tuhan, Allahmu, kudus" (Im. 19:2).

Lalu serta merta ada yang mengatakan bahwa dosa berasal dari Iblis. Iblislah yang pertama kali memberontak terhadap Allah dan ia ingin mengajak manusia ciptaan Allah untuk juga memberontak terhadap Allah. Alkitab berkata, "Barangsiapa yang tetap berbuat dosa, berasal dari Iblis, sebab Iblis berbuat dosa dari mulanya” (1 Yoh. 3:8). Iblis menggoda Hawa untuk melanggar peraturan atau larangan Allah seperti yang ia telah lakukan. Selanjutnya, Hawa menggoda Adam untuk menuruti keinginan Iblis. Akhirnya, Iblis berhasil membawa Adam dan Hawa menuruti keinginannya. Rasul Yohanes berkata, "Iblislah yang menjadi bapamu dan kamu ingin melakukan keinginankeinginan bapamu. la adalah pembunuh manusia sejak semula dan tidak hidup dalam kebenaran, sebab di dalam dia tidak ada kebenaran" (Yoh. 8:44).

Pada sisi lain, memang Allah yang memberi kehendak bebas manusia sehingga manusia bisa memilih menaati Allah atau melawan Allah. Tetapi itu bukan berarti Allah 
yang menghendaki manusia berdosa. Manusialah yang memberontak dan berbuat dosa atas keinginannya sendiri ketika ia memilih mengikuti keinginan Iblis.

Jadi sesungguhnya diri manusia sendiri yang bertanggungjawab atas dosa. Tong mengatakan, "Apakah Alkitab mengatakan, "Akui dosa-dosamu sendiri ditambah akui dosa-dosa setan." Tidak ada. Alkitab mengatakan, "jika kita mengakui dosa-dosa kita sendiri, maka Allah adalah setia dan adil" (1 Yoh. 1:9). Diri menjadi sumber, menjadi penanggungjawab dosa. Meskipun ada godaan, tidak berarti bahwa manusia tidak harus bertanggungjawab".

\section{Aspek-Aspek Dosa}

Pengertian aspek disini adalah apa saja yang merupakan sisi-sisi yang kelihatan atau pemunculan, pada dosa yang sangat mempengaruhi manusia berdosa. Kejatuhan manusia dalam dosa telah meracuni setiap kemampuan manusia, sehingga seluruh keberadaan manusia ternoda dosa. Pikiran manusia yang menolak kebenaran Allah (1 Kor. 2:14); Perasaan telah tumpul sehingga tidak sensitif lagi terhadap dosa (Ef. 4:19); Perkataan dan perbuatan penuh dengan dosa (Rm. 3:13-16). Hati manusia adalah hati yang licik (Yer. 17:9). Keberdosaan manusia bukan hanya untuk pelanggaran yang terlihat tetapi bahkan yang tidak terlihat (Mat. 5:21-22; 27-28). Jadi seluruh aspek hidup manusia telah jatuh ke dalam dosa Dalam hal ini akan dibahas aspek dosa sebagai status, habitus dan aktus.

\section{Dosa Sebagai Status}

Secara status, sejak Adam dan Hawa, dosa sudah ada di hadapan manusia, tentunya sebagai akibat dari kejatuhan mereka. Manusia adalah makhluk yang berdosa dan karena itu sekaligus seteru Allah. Dikatakan bahwa semua manusia telah berbuat dosa dan telah kehilangan kemuliaan Allah (Rm. 3:23). Stephen Tong melihatnya dan mengatakannya "sebagai pergeseran dari status yang seharusnya. Pergeseran status itu sendiri adalah pokok dan sumber dari segala macam dosa yang mungkin diperbuat oleh umat manusia". Ada pendapat yang mengemukakan bahwa bayi yang lahir itu seperti kertas yang putih. Akan jadi apa kertas itu nantinya tergantung dari yang menulis dan yang menggambar di atasnya. Pandangan tersebut adalah pandangan yang salah.

Jika manusia berdosa sejak dari kandungan, berarti ketika manusia dilahirkan sebagai bayi, ia pun telah berdosa. Status keberdosaan dengan sendirinya melekat kepada setiap manusia yang hidup di bumi dan tidak bisa lepas, selama Allah sendiri tidak melepaskannya. Berkhof menyimpulkannya dengan mengatakan: Dosa ini disebut sebagai "dosa asal" karena diperoleh dari akar mula-mula umat manusia; karena dosa ini ada dalam hidup manusia secara individu sejak ia mulai dilahirkan dan dengan demikian tidak dapat dianggap sebagai hasil dari peniruan; dan arena dosa ini adalah akar yang terdalam dari semua dosa sesungguhnya yang mengotori seluruh hidup manusia".

Status ini pun diikuti oleh rasa bersalah yang nyata, konkrit, dan objektif. Seorang terpidana tetaplah seorang terpidana sampai hakim memutuskan bahwa ia tidak lagi menjadi terpidana, atau ia telah memenuhi tuntutan hukum yang dibebankan kepadanya. Setiap manusia yang berdosa tetap harus mempertanggungjawabkan keberdosaannya di hadapan Allah karena secara legal telah menyeleweng dari standar legal yang telah ditetapkan Allah. 
Itu sebabnya, manusia oleh naturnya telah memiliki keinginan yang tidak dapat ditahan untuk senantiasa membeloknya ke arah yang jahat. la tak mampu mencari dan mencintai kesempurnaan spiritual, mencari dan melakukan hal-hal spiritual, hal-hal yang berasal dari Allah yang menuju kepada keselamatan.

\section{Dosa Sebagai Habitus}

Dunia tempat manusia dilahirkan adalah dunia yang telah berdosa. Lingkungan tempat manusia dilahirkan ada dalam kondisi berdosa. Hal ini juga memungkinkan semua manusia memiliki kecenderungan berdosa dan kecenderungan berbuat jahat. Kondisi keberdosaan juga menyebabkan manusia menularkan kebiasaan berdosa yang semuanya membawa kebobrokan. Bergaul dengan orang fasik/jahat akan menyebabkan orang juga menjadi fasik (Ams. 11:9). Seseorang yang dibesarkan dan tinggal dalam lingkungan yang jahat akan mudah untuk jatuh dalam kejahatan, apalagi pada dasarnya ia juga sudah jahat. Jika demikian, tidak seorang manusia pun dapat lolos dari dosa.

Itu berarti bahwa dosa adalah sesuatu yang lebih dari sekedar suatu ketidaktaatan, Richard J. Foster mengatakan: Kita telah terbiasa untuk berpikir tentang dosa sebagai perbuatan ketidaktaatan individual terhadap Allah. Memang pernyataan ini ada kebenaran juga, tetapi di Alkitab dosa bukan sekedar ketidaktaatan. Dalam kitab Roma, Rasul Paulus sering menunjukan dosa sebagai suatu keadaan yang mengganggu umat manusia (mis. Roma 3:9-18). Sebagai suatu keadaan, dosa bekerja melalui anggota-anggota tubuh; yaitu kebiasaan-kebiasaan yang telah mendarah daging dalam tubuh (Roma 7:5). Tidak ada perbudakan lain yang dapat dibandingkan dengan perbudakan kebiasaan-kebiasaan dosa yang mendarah daging.

\section{Dosa Sebagai Aktus}

Dosa adalah sesuatu yang sifatnya adalah pribadi. Artinya, dosa merupakan sesuatu yang dilakukan manusia secara pribadi. Manusia selalu melakukan dosa secara aktif. Itulah sebabnya semua manusia memiliki pengalaman berbuat dosa. Semua tindakan manusia selalu menuju kepada pelanggaran terhadap ketetapan Allah. Itu sebabnya Yohanes 8:34b "setiap orang yang berbuat dosa adalah hamba dosa". Istilah 'hamba' perlu ditekankan di sini. Dengan manusia dinyatakan sebagai 'hamba dosa', itu jelas menunjukkan bahwa ia selalu atau terus menerus menuruti dosa, dan tidak bisa berbuat baik. Ini dinyatakan secara lebih jelas oleh Roma 6:16-17, 20-21. Secara khusus Roma 6: 20 yang berbunyi: "Sebab waktu kamu hamba dosa, kamu bebas dari kebenaran". Istilah 'bebas dari kebenaran' itu jelas menunjukkan bahwa manusia berdosa itu tidak bisa berbuat apapun yang benar. Perbuatan dosa harus dipertanggungjawabkan kepada Allah secara pribadi. Sebenarnya hal ini adalah apa yang telah diketahui oleh semua orang, seperti tanggapan terhadap persitiwa yang telah terjadi di desa Jambo Dalam, Kecamatan Plimbang, Bireuen, Aceh. Bentrokan berdarah terjadi antara warga karena berbeda keyakinan itu. Satu pihak menuduh pihak lain telah menyebarkan aliran sesat, pihak yang dituduh melakukan pembelaan karena meyakini kebenaran ajaran yang dipercayai itu, mereka nyaman dalam menjalankan ibadahnya. Akibat bentrokan itu, tiga orang meninggal dunia, sepuluh orang lainnya menderita luka parah, satu unit rumah turut hangus dibakar massa. Kompasiana memuat artikel yang mengatakan: Kalau tidak percaya, jangan marah. Kalau berbeda kepercayaan, jangan memaksa, apalagi saling menyerang sampai 
berkorban nyawa. Kalau dia salah, dialah yang dosa dan kalau dia benar, dialah yang dapat pahala. Keyakinan atau kepercayaan adalah hal yang pribadi, dan tidak ada dasarnya untuk saling mencela, saling memaksa, apalagi sampai memutuskan hubungan persaudaraan. Kenapa saling menyalahkan karena perbedaan kepercayaan itu, cobalah bertanya apakah telah pernah menyampaikan kebenaran yang dipercaya atau diyakini itu, kalau belum, wajar saja bilamana terjadi berbeda keyakinan, Kalau dianalogkan, salahkah bila ada pihak yang belum saling kenal, tetapi salah satu pihak telah mencintai dan dicintai pihak lain ? Tentu saja tidak salah, kenal saja belum, apalagi pendekatan, Lalu kenapa uring-uringan bilamana si dia yang dicintai telah memilih orang lain sebagai tambatan hatinya?

Jadi ketika seseorang berbuat dosa maka itu adalah keputusan dan pilihannya secara pribadi, dilakukan dalam kehendak dan pengetahuan akan akibat dan konsekuensi yang akan ditanggung atau dipikulnya.

\section{Akibat Dosa}

Dosa yang telah dilakukan oleh manusia sudah pasti berakibat, dan bahkan akibatnya parah.

\section{Dosa Merusak Hubungan Antara Manusia Dengan Allah.}

Dampak yang paling utama berkaitan dengan dosa yang dilakukan oleh manusia adalah dalam hubungannya dengan Allah. Di mata Allah manusia sudah mati dan akan menuju maut (Rm. 3:23; 6: 23). Manusia tidak layak untuk menghadap Allah. Pengusiran Adam dan Hawa dari Taman Eden ke luar, merupakan ungkapan geografis dari pemisahan spiritual manusia dari Allah, serta ketidaklayakan untuk menghadap Dia dan menikmati keakraban dengan Dia (Kej. 3: 23). Malaikat dengan pedang yang bernyala-nyala yang menutupi jalan menuju Eden melambangkan kebenaran mengerikan bahwa dalam dosanya, manusia menghadapi pertentangan dan perlawanan dari Allah, yaitu murka Allah (Kej. 3:24; Mat. 3:7; 1 Tes. 1:10).

Manusia tidak sanggup lagi melakukan kehendak Allah. Meskipun Allah memanggil dan memerintahkan manusia dan menawarkan kepadanya untuk jalan kehidupan, kebenaran dan kebebasan, manusia tidak sanggup lagi menjawab panggilan Allah itu sepenuhnya. Manusia tidak bebas dan tidak sanggup untuk menyesuaikan diri dengan rencana Allah karena telah menjadi budak dosa (Yoh. 8:34; Rm. 7:21-23).

Manusia tidak benar di mata Allah. Kegagalan untuk mematuhi hukum dan kehendak Allah membuat manusia berada di bawah kutukan hukum, rasa bersalah dan penghukuman yang makin bertambah bagi pelanggar hukum (Rm. 5:12; Ul. 27: 26; Gal. 3:10).

Manusia tidak peka lagi terhadap Firman Allah. Allah berbicara baik melalui firman yang tertulis, yaitu Taurat, Alkitab dan juga lisan melalui nabi-nabi-Nya kepada umat manusia. Akan tetapi dosa telah membuat manusia menjadi bebal dan lebih memilih untuk tidak mentaati Firman Allah. Akhirnya manusia menjadi tidak mengenal Allah dan tidak mengerti hal-hal mengenai Roh. Hal-hal ini membuat manusia menjadi angkuh dan dalam lingkup keagamaan, keangkuhan ini diungkapkan sebagai pembenaran diri. Manusia menentukan sendiri norma-norma bagi dirinya dan membenarkan dirinya menurut norma-norma itu. Manusia mencari-cari alasan bagi dosa dan merasa yakin di hadapan Allah karena prestasi-prestasi moral dan religiusnya 
dengan berbagai macam agama dan kepercayaannya. Ada juga yang kemudian menolak eksistensi Allah secara teori (ateisme). Namun itu semua sesungguhnya hanya untuk bersembunyi dari Allah (seperti Adam dam Hawa di Eden) dan untuk menghindari "keseraman" apabila berdiri di hadapan Allah dengan kesalahannya terpampang di depan.

\section{Dosa Merusak Hubungan Antara Manusia Dengan Dirinya Sendiri.}

Manusia kehilangan arah batin dan hidup dalam sejuta konflik dalam dirinya (Rm. 7:23). Pengaruh dosa nyata dalam penipuan diri sendiri. Manusia tidak lagi mampu menilai dirinya dengan benar dan tepat. Dosa telah membuat manusia tidak lagi mampu memandang dirinya sebagai ciptaan Allah yang mulia (Mzm. 8:6). Manusia menjadi malu dengan dirinya sendiri, batinnya senantiasa bergejolak mencari arah kehidupan ini. Bahkan terkadang manusia tidak dapat berdamai dengan dirinya sendiri. Ketika Allah menciptakan manusia, la menciptakan manusia segambar dan serupa dengan-Nya. Dengan kata lain, mereka sangat mengenal siapa diri mereka, yaitu ciptaan Allah yang mengakibatkan Allah mengatakan ciptaan-Nya sungguh amat baik (Kej. 1:31). Tetapi, dosa merusak segalanya.

Dosa mengakibatkan manusia tidak lagi mengenal pribadinya sendiri, sehingga tidak usah heran, studi psikologi muncul bukan untuk mengembalikan pribadi manusia kepada Sumber yaitu Penciptanya, tetapi menafsirkan ulang pribadi manusia dari perspektif manusia itu sendiri. Mereka ingin meniadakan Allah untuk mengenal manusia, tetapi herannya memakai standar manusia yang sama berdosanya untuk mengenal diri manusia. Sesuatu yang mustahil, apabila manusia yang berdosa samasama dapat mengenal manusia, padahal dosa nantinya mengakibatkan rusaknya hubungan manusia dengan manusia. Peralihan ini membuat manusia menjadi lebih baik.

Selanjutnya, dosa mengakibatkan manusia yang tak mengenal jati dirinya berusaha menonjolkan jati dirinya dengan kelakuan-kelakuan aneh, misalnya homo, lesbian, banci, pergi ke diskotik (dugem: dunia gemerlap). Mereka sudah melupakan esensi jati diri mereka dan menggantinya dengan jati diri palsu untuk mendapatkan penghormatan dari orang lain. Semula Allah tidak menciptakan manusia untuk mati dan kembali menjadi tanah, tetapi dosa menyebabkan manusia pasti mengalami kematian dan menjadi tanah kembali. Alkitab mencatat, "Dengan berpeluh engkau akan mencari makananmu, sampai engkau kembali lagi menjadi tanah" (Kej. 3:19). Kehilangan kemuliaan Allah menyebabkan kualitas tubuh manusia menurun drastis. Kematian jasmani merupakan konsekuensi dari keberdosaan manusia, seperti dikatakan oleh Paulus, "Sebab upah dosa ialah maut" (Rm. 6:23).

Kehilangan kemuliaan Allah membuat manusia akan hidup tanpa hormat dan kemuliaan, pendidikan akan menolak kebenaran, hak-hak manusia tidak mempunyai kebaikan, pengetahuan tanpa hikmat, pernikahan tanpa kasih, dan ilmu pengetahuan tanpa hati nurani/kesadaran, kebebasan tanpa kontrol. Jadi akibat dosa yang membuat manusia mengalami keadaan bersalah (Inggris: 'guilt'): “... dan kesalahanku tidaklah kusembunyikan... dan Engkau mengampuni kesalahan dosaku” (Mzm. 32:5). Kata bersalah menunjukkan keadaan bersalah itu:"... dengan demikian engkau mendatangkan kesalahan atas kami” (Kej. 26:10). Barangsiapa melakukan dosa, dia menjadi "bersalah" baik di hadapan Allah maupun di hadapan suara hatinya sendiri. Kejahatan saudara-saudaranya Yusuf masih mengejar mereka banyak tahun kemudian 
(Kej. 42:21). Dalam Taurat Musa orang melakukan pelanggaran diingatkan bahwa mereka dalam keadaan bersalah (Im. 5:1-6). Hati orang berdosa "memukulnya" (1 Sam. 24:5; 2 Sam. 24:10), dan suara hati Daud terus menuduh dia sampai mengaku dosanya (Mzm. 32:3-5).

\section{Dosa Merusak Hubungan Antara Manusia Dengan Manusia}

Terputusnya hubungan manusia dengan Allah langsung mempengaruhi hubungan manusia dengan sesamanya. Adam menuduh Hawa dan menyalahkannya sebagai penyebab dosa (Kej. 3:12). Kisah kejatuhan manusia segera diikuti dengan peristiwa pembunuhan Habel (Kej. 4:1-6). Dosa membuat manusia tidak lagi bisa saling mengasihi dengan tulus, yang ada adalah konflik, perpecahan antar bangsa/suku, prasangka rasial, dan terbentuknya blok-blok internasional yang saling bermusuhan. Dosa membuat perpecahan, pemisahan dan pertikaian antara manusia dan sesamanya baik di dalam kelompok masyarakat, agama, sosial, keluarga bahkan gereja. Dosa membuat manusia "mengeksploitasi" sesamanya. Eksploitasi ini dapat dengan jelas kita lihat dalam hubungan antara pria dan wanita. Sejarah mencatat kaum pria telah mendominasi wanita dengan kekerasannya. Wanita digunakan bagi kepentingan egois pria, penolakan pria memberikan persamaan hak dan martabat kepada wanita merupakan kenyataan yang tidak dapat dipungkiri.

Dalam surat Roma 3:10-18, Paulus menjabarkan tentang akibat dosa di dalam wilayah pikiran, perkataan dan tindakan lalu berakhir dengan suatu kesimpulan bahwa sebenarnya akibat dosa berdasar pada esensi dosa yaitu tidak takut akan Allah (Rm. 3:18). Akibat dosa inilah yang disebut mempengaruhi terputusnya atau rusaknya hubungan manusia dengan manusia. Manusia dengan manusia tidak lagi seperti manusia pertama ketika sebelum berdosa, saling bersahabat, tetapi mulai bermusuhan dan saling menyalahkan.

Ketika Adam ditanya oleh Tuhan tentang alasannya telah memakan buah pengetahuan yang baik dan jahat, Adam bukan mempertanggungjawabkan perbuatannya, malahan menuduh Hawa. Itulah akibat dosa pada hubungan interpersonal atau pribadi dengan pribadi yaitu saling menyalahkan. Tidak heran, di abad postmodern ini, istilah "mengkambinghitamkan" menjadi populer. Dirinya yang bersalah tetapi tidak berani mempertanggungjawabkan kesalahannya, malahan menuduh orang lain bahkan sahabat yang terdekat sekalipun yang bersalah agar dapat lolos dari pertanggungjawaban itu. Disamping itu, adalah rahasia umum, bahwa untuk menutupi realita dosa, orang rela menyuap para pejabat pemerintah (misalnya hakim, dII). Betapa memprihatinkan, bahkan akibat dosa manusia, orang tidak lagi mempercayai orang lain bahkan sahabatnya sendiri.

Manusia adalah serigala bagi sesamanya. Ungkapan ini ada benarnya karena berdasarkan fakta manusia bisa saling merugikan dan saling mencelakakan di dalam upayanya mempertahankan hidup dan mengejar kesenangan hidup. Hubungan antar manusia tidak lagi harmonis sejak fakta kejatuhan dalam dosa. Sejarah umat manusia berikutnya melengkapi daftar kejahatan (Kej. 4:8, 19, 23, 24; 6:2, 3, 5). Dan timbunan kejahatan yang merajalela itu mencapai kesudahannya dalam pemusnahan umat manusia, kecuali 8 orang (Kej. 6:7, 13; 7:21-24). Kejatuhan ke dalam dosa berakibat tetap dan menyeluruh, tidak hanya menimpa Adam dan Hawa, tapi juga menimpa segenap keturunan mereka; dalam ihwal dosa dan kejahatan terkandung solidaritas insani, yakni sama-sama langsung terhisab dalam perbuatan dosa itu dan menanggung 
segala akibatnya. Manusia saling mempersalahkan (Kej. 3:12-13). Peristiwa Kain membunuh Habel merupakan bukti selanjutnya. Sejak saat itu manusia selalu harus berhati-hati dalam berhubungan dengan sesamanya. Kalau mau jujur, orang-orang yang berselisih tajam, saling membenci, saling mengecewakan, bahkan saling membunuh, umumnya adalah orang-orang yang saling kenal, bahkan tidak jarang mereka mempunyai kedekatan secara emosional. Manusia menjadi makhluk yang tinggi egosentrisnya, dan itu sebabnya mengapa manusia menjadi sulit bersekutu dengan sesamanya. Semuanya hanya menuruti hawa nafsunya sendiri. Keadaan ini sebenarnya bersumber dari rusaknya hubungan manusia dengan Allah sehingga manusia tidak tahu membedakan manakah kehendak Allah dan yang bukan.

\section{Dosa Merusak Hubungan Manusia Dengan Alam}

Sejak manusia jatuh dalam dosa, manusia telah kehilangan keharmonisannya dengan alam ini. Manusia yang seharusnya memelihara dan mengusahakan bumi bagi kemuliaan Tuhan (Kej. 2:15) malah mengeksploitasi secara sembarangan sehingga mengakibatkan kerusakan alam ini (hutan menjadi gundul, banjir dsb). Udara, air, dan tanah menjadi kotor oleh polusi yang disebabkan keserakahan manusia.

Penyataan Allah yang pertama dan orisinal adalah alam. Segenap alam dan semua kehidupan menjadi tempat kudus dimana manusia menghormati Allah. Pada mulanya Allah menciptakan manusia dan seluruh alam semesta dalam suatu keadaan yang harmonis dan sungguh amat baik. Alkitab mencatat, "Maka Allah melihat segala yang dijadikan-Nya itu sungguh amat baik" (Kej. 1:31). Manusia membutuhkan alam untuk mengaktualisasikan dirinya dan alam membutuhkan manusia untuk memelihara dan menatanya. Manusia dan alam memiliki hubungan interdependensi yang kuat dan erat. Namun, dosa menyebabkan manusia tidak mampu memelihara dan mengusahakan alam, tetapi justru semena-mena karena keserakahannya. Akibatakibat dari kejatuhan ke dalam dosa meluas sampai ke alam semesta. 'Terkutuklah tanah ini karena engkau' (Kej. 3:17; Rm. 8:20). Manusia adalah mahkota seluruh ciptaan, dijadikan menurut gambar Allah, dan karena itu merupakan wakil Allah, diberi kuasa untuk memelihara (Kej. 1:26). Bencana kejatuhan manusia ke dalam dosa mendatangkan bencana kutuk atas alam semesta, yang tadinya atasnya manusia telah dikaruniai kuasa. Dosa adalah peristiwa dalam kawasan rohani manusia, tapi akibatnya menimpa seluruh alam semesta. Semak duri dan belukar yang tidak ada dalam Kejadian 1-2, akhirnya muncul di bumi yang amat sangat baik setelah kejatuhan manusia.

Penampakannya pada zaman sekarang ini adalah teknologi yang dibuat manusia cenderung ditujukan untuk merusak alam sehingga dunia sekarang dihantui oleh krisis lingkungan hidup seperti bocornya ozon, banjir karena gundulnya hutan, efek rumah kaca, dan sebagainya yang dapat menimbulkan berbagai macam penyakit, kesengsaraan bahkan kepunahan makhluk hidup, terkikisnya kekayaan, krisis air bersih, dan sebagainya. Persoalan utama bukanlah karena alam pada dasarnya tidak baik, tetapi karena manusia yang menyebabkan alam tidak lagi harmonis dan seimbang. Makin lama tanah semakin berkurang kesuburannya, semakin berkurang hasilnya. Bukan hanya itu, pelaksanaan mandat mengelola alam dilakukan manusia secara tidak bertanggung jawab telah mengakibatkan banyak bencana. Padahal, tugas mengelola dan memelihara bumi ada pada pundak manusia (Kej. 1:28; 2:15). Krisis 
lingkungan diciptakan oleh manusia dan membawa ancaman bagi manusia sendiri. Bumi sedang menuju kehancuran dan kemusnahan.

\section{Dosa Merusak Manusia Dalam Hubungannya Dengan Waktu}

Manusia yang jatuh ke dalam dosa, hidup dalam waktu yang dibatasi karena dosa itu. Dosa membuat manusia kehilangan kekekalan (Kej. 2:17; 3:19), hari-hari manusia menjadi terbatas (Mzm. 90:9-10). Manusia harus menghadapi kematian sebagai akhir hidupnya.

\section{Dosa Membuat Manusia Menderita}

Pada waktu manusia jatuh dalam dosa, maka Allah berfirman, "Susah payahmu waktu mengandung akan Ku buat sangat banyak; dengan kesakitan engkau akan melahirkan anakmu,... maka terkutuklah tanah karena engkau, dengan bersusah payah engkau akan mencari rejekimu,... dengan berpeluh engkau akan mencari makananmu sampai engkau kembali lagi menjadi tanah" (Kej. 3:16-19). Karena keberdosaannya, manusia jadinya akrab dengan penderitaan fisik dan psikis seumur hidupnya. Bukan berarti bahwa orang percaya sejak bertobat dan percaya kepada Yesus Kristus manusia tidak lagi akan sakit dan menderita. Keputusan untuk mengikut Tuhan juga diiringi dengan penderitaan yang harus dipikul. Namun, penderitaan bersama Kristus justru mendatangkan kemuliaan surgawi, sementara penderitaan karena dosa akan mendatangkan kesengsaraan kekal. Pengertian penderitaan di sini adalah sejak manusia jatuh dalam dosa, Allah membiarkan manusia mengalami banyak penderitaan sehingga penderitaan menjadi akrab dengan manusia seumur hidupnya. Akibat dosa ialah hukuman dan penderitaan. Penderitaan yang meliputi kenyataan kehilangan persekutuan dengan Allah, (Kej. 3:8; 3:24) serta berada dibawa murka dan kutukan Allah (Ef. 2:3; Gal. 3:10) yang melahirkan kehampaan serta ketidakberdayaan dan masih harus ditambah dengan penderitaan hidup (Rat. 3:29) yang tak mungkin dihindari oleh siapa pun dan kuasa maut ( $\mathrm{Rm}$. 6:23) yang berlaku universal, dan mengalami siksaan kekal di Neraka (Mat. 25:41).

\section{Dosa Membuat Manusia Menerima Hukuman}

Hukuman (punishment) adalah sebuah cara untuk mengarahkan sebuah tingkah laku agar sesuai dengan tingkah laku yang berlaku secara umum. Dalam hal ini, hukuman diberikan ketika sebuah tingkah laku yang tidak diharapkan ditampilkan oleh orang yang bersangkutan atau orang yang bersangkutan tidak memberikan respon atau tidak menampilkan sebuah tingkah laku yang diharapkan. Secara umum, hukuman dalam hukum adalah sanksi fisik maupun psikis untuk setiap kesalahan atau pelanggaran yang dilakukan oleh seseorang. Diharapkan bahwa hukuman itu sendiri akan mengajarkan tentang apa yang tidak boleh dilakukan.

\section{Hukuman Sebagai Akibat Langsung Dari Dosa}

Alkitab secara tegas mengatakan bahwa setiap dosa yang dilakukan oleh seseorang pasti disusul dengan hukumannya, sebagaimana dikatakan bahwa: "... kamu akan mengalami bahwa dosamu itu akan menimpa kamu"(Bil. 32:23), dan "mereka menabur angin, maka mereka akan menuai puting beliung" (Hos. 8:7). Dengan demikian, dosa seseorang sering secara langsung mengakibatkan 
hukumannya: "sesungguhnya, bukan Aku yang mereka sakiti, melainkan diri mereka sendiri sehingga mereka malu" (Yer. 7:19).

\section{Hukuman Yang Diberikan Oleh Allah, Yaitu Hukuman Kekal}

Mengingat bahwa dosa adalah pelanggaran terhadap Allah maka hukuman dosa ialah bahwa pada dasarnya manusia dipisahkan dari pencipta-Nya (Yes. 59:2). Terlebih pada hukuman terakhir, mengingat bumi adalah milik Tuhan, maka orang berdosa harus dihapus dari bumi ini (Mzm. 104:35). Hal ini sesuai dengan perintah yang Tuhan berikan kepada Adam, bahwa dia akan pasti mati kalau dia melanggar ketetapan Tuhan (Kej. 2:17). Melalui Yehezkiel Tuhan menegaskan sekali lagi: "Dan orang yang berbuat dosa, itu yang harus mati"(Yeh. 18:4). Hukuman atas dosa tidak hanya sekedar kematian fisik; orang yang berbuat dosa terhadap Tuhan dan tidak bertobat, orang itu tidak akan mewarisi kehidupan kekal, sebab namanya "dihapuskan dari kitab kehidupan" (Mzm. 69:28) dan mereka akan tinggal di neraka (Mzm. 49:14), sama sekali terpisah dari Allah dan kehidupan. Dosa mendatangkan maut dan kebinasaan bagi manusia (Rm. 6:23). Allah telah menyiapkan hukuman kekal sebagai tempat kekal manusia yang tidak kembali kepada-Nya, yaitu neraka. Di dalam neraka, manusia mengalami keterpisahan dari Allah. Tempat ini merupakan tempat yang mengerikan di mana manusia tidak akan pernah mati lagi secara fisik. la akan menderita karena ada api yang tak terpadamkan, ratap tangis dan kertakan gigi, ada kegelapan yang mengerikan (Mat. 25:30) serta ada ulat yang terus-menerus menggerogoti tubuh manusia berdosa (Mrk. 9:43-48). Jika manusia sudah masuk dalam neraka, ia tidak mungkin dapat keluar lagi, tidak mungkin ada kesempatan untuk bertobat.

\section{Jalan Keluar Dari Dosa}

Dosa itu realitas yang tak dapat dihindari oleh manusia. Hal ini senada dengan ungkapan Paulus yang berkata bahwa semua manusia telah berbuat dosa dan telah kehilangan kemuliaan Allah (Rm. 3:23). Jadi, manusia secara pribadi bertanggung jawab dan tak dapat membenarkan diri dengan berbagai alasan dan perbuatan. Semua perbuatan dosa manusia akan mendatangkan hukuman yang mengerikan bagi manusia.

Oleh karena itu, manusia perlu mengetahui jalan keluar dari dosa. Jalan keluar dari dosa dan hukuman dosa tidak dapat dikerjakan dan diusahakan oleh manusia. Artinya, sekalipun manusia berbuat banyak amal dan kebajikan, tetap saja ia tidak akan mampu membawanya bebas dari konsekuensi dosa karena secara esensial dirinya masih berada dalam status berdosa. Manusia juga tidak dapat terhindar dari konsekuensi dosa hanya karena melakukan banyak ibadah dan usaha-usaha untuk mendekatkan diri kepada Allah. Jalan keluar dari dosa hanya dapat dikerjakan oleh Allah sendiri. Karya Allah, yang akhirnya disebut sebagai jalan keluar dari dosa disebut pengampunan dosa. Pengampunan dosa itu adalah karya Allah yang terjadi karena anugerah-Nya.

BJ. Boland mengatakan bahwa pengampuan dosa itu sekali-kali tidak berarti bahwa Allah itu membiarkan serta memaafkan begitu saja dosa-dosa manusia. Tetapi siapa yang pernah berhadapan dengan salib Kristus, ia sadar bahwa anugerah Allah itu tidaklah murah. Pengampunan dosa itu terjadi karena Allah sendiri harus tetap menghukum dosa, oleh karena itu Yesus Kristus harus mati demi pembebasan manusia dari dosa. Demikianlah, Allah berkata bahwa siapa yang percaya kepada Kristus akan 
beroleh hidup kekal dan tidak memperoleh hukuman (Yoh. 3:16). Karena itu sekali lagi, jalan keluar dari dosa hanya bisa diterima dalam iman kepada Yesus Kristus yang mati untuk menebus dari hukuman dosa.

Penebusan dari Yesus Kristus berdampak kepada keselamatan dan kehidupan yang kekal. Suatu anugerah yang paling mahal dan mulia sejak kejatuhan manusia di dalam dosa. Penebusan itu ditawarkan bagi semua orang, penawaran ini memerlukan respon manusia. Jenis tindakan yang disyaratkan oleh Allah sederhana saja, bukan melakukan syarat melakukan amal ibadah agamawi yang rumit, yang harus melibatkan tindakan pekerjaan berat, harus melakukan ini dan melakukan itu, tindakan ini juga tidak memerlukan pengeluaran biaya. Tindakan yang diperlukan sungguhlah sederhanya, yang diperlukan hanyalah respon, dan respon itu adalah sikap percaya.

Kata "pisteuôn - percaya" dalam Yohanes 3:16 adalah "verba-partisip". Modus partisip digunakan untuk menggambarkan partisipasi dalam satu tindakan yang dilakukan oleh verba. pisteuôn juga dalam bentuk present-active. Present tense dalam Bahasa Yunani lebih menunjuk kepada sesuatu yang sedang dilakukan. Jadi lebih mendekati present continuous dari pada simple present, yaitu suatu pekerjaan/perbuatan yang sedang dilakukan atau yang dilakukan berulang-ulang dalam waktu sekarang.

Dengan demikian, jalan keluar dari dosa adalah semata-mata merupakan inisiatif Allah yaitu: pertama, Allah mencari manusia yang berdosa. Sejak pemberontakan manusia pertama justru Allah sendiri yang mencari si pemberontak (Kej. 3:9) untuk memberikan kesempatan kepadanya untuk berpaling. Kedua, manusia harus mengaku dosa. Dalam masalah dosa, manusia senantiasa berhadapan dengan Allah yang Maha Kudus, kesadaran ini selalu harus lebih tinggi dari rasa malu di hadapan sesama. Kesadaran bahwa tiap dosa merupakan pemberontakan secara langsung terhadap Allah yang kudus dan yang menginginkan pertobatan manusia, membuat orang percaya yang berkedudukan tinggi mengabaikan rasa malu terhadap mereka yang dipimpin sehingga mereka mengaku dengan jujur segala pelanggaran mereka ( $\mathrm{Mzm}$. 32:3-5; 51:5-6; Yes. 6:5). Pengakuan saja juga tidak cukup melainkan harus diikuti tekad untuk meninggalkan dosa itu (Ams. 28:13) serta mentaati kehendak Tuhan secara praktis dalam kehidupan sehari-hari (Yer. 18:11b ; Am. 5:24). Ketiga, Allah mau mengampuni. Kenyataan bahwa Tuhan mau mengampuni dan tidak membalas kejahatan manusia adalah suatu keajaiban yang sangat besar di mana manusia tidak layak untuk menerimannya. Pemazmur bersyukur "pada-Mu ada pengampunan", tetapi ia menambahkan kalimat yang penting: "supaya Engkau ditakuti orang" (Mzm. 130:4).

Petrus Octavianus dalam bukunya "Rahasia Kemenangan Atas Dosa", menuliskan bahwa hanya di dalam Alkitab sajalah terdapat jawaban atas pertanyaan mungkinkah seseorang mempunyai satu hidup baru yang penuh kemenangan di dalam dunia ini? Kemenangan atas dosa?

Selanjutnya dijelaskan bahwa ada tiga hal yang berperan bagi manusia untuk dapat mengalami dan menemukan jalan keluar atau kemenangan atas dosa: (1) Kemenangan atas dosa di bawah anugerah salib Kristus. Hanya di dalam Tuhan Yesus Kristus ada kemenangan atas dosa-dosa. Kuasa salib Kristus mempunyai dua fungsi, yaitu menghilangkan kuasa dosa (Rm. 6:6) "Karena kita tahu, bahwa manusia lama kita telah turut disalibkan, supaya tubuh dosa kita hilang kuasanya, agar jangan kita menghambakan diri lagi kepada dosa)" dan melenyapkan atau menghapus 
dosa "Sebab kematian-Nya adalah kematian terhadap dosa, satu kali dan untuk selama-lamanya, dan kehidupanNya adalah kehidupan bagi Allah" (Rm. 6:10).

Dengan demikian, salib Kristus memiliki arti yang menggambarkan bahwa manusia bisa mendapat kemenangan atas dosa, di mana Yesus tersalib bagi manusia berdosa. Dalam 1 Korintus 15:3, dikatakan: "... Kristus telah mati karena dosa-dosa

kita,..." Kristus mati karena segala dosa manusia. Tidak ada seorang manusiapun yang dapat menolong dirinya sendiri dari dosanya. Firman Allah berkata di dalam Roma 3:23: "Karena semua orang telah berbuat dosa dan telah kehilangan kemuliaan Allah". Semua orang tidak ada kecuali ialah sekalian raja-raja, orang-orang besar, orang-orang biasa, semua orang telah jatuh ke dalam dosa. Dan tidak ada seorang manusia pun yang dapat sampai kepada Allah Bapa, kecuali sudah ditebus oleh darah Yesus Kristus.

Kemudian, manusia lama telah turut disalibkan. Operasi salib Kristus membawa manusia lama yaitu tubuh dosa telah tersalib beserta Kristus. Semua yang lama sudah berlalu, sekarang sudah memiliki hidup baru, hidup di dalam Tuhan Yesus dalam Galatia 5:24 tertulis: "Ia telah melepaskan kita dari kuasa kegelapan dan memindahkan kita ke dalam Kerajaan AnakNya yang kekasih..."

Selanjutnya, manusia mati setiap hari terhadap dosa. Seorang Kristen yang menang atas dosa ialah seorang Kristen yang memandang dirinya mati setiap hari terhadap dosa yang timbul dari watak-tabiat: setiap dosa yang menggoda dari luar. (2) Berjalan dalam terang Firman Tuhan. Berjalan dalam terang adalah syarat/jalan kepada kemenangan atas dosa. Hidup dalam terang menuntut suatu hidup sederhana, sederhana mengaku salah dan dosa bila bersalah atau jatuh dalam dosa. Segera mengaku dosa dan minta maaf atau ampun membuat hidup bebas, jujur, ikhlas dan ringan. (3) Kemenangan di dalam Roh Kudus. Inilah hidup yang dipimpin oleh Roh Kudus, orang yang percaya dipindahkan dari hidup yang duniawi kepada hidup yang rohani, hidup yang dikelilingi dan diarahkan oleh Roh Allah.

\section{Kesimpulan}

Dosa adalah pemisah antara Allah dan manusia, dan dosa merupakan ketidaktaan manusia atas perintah-perintah Allah. Konsekuensi dari dosa, manusia berada di bawah kutukan dan kehilangan kemuliaan Allah. Bahkan merusak hubungan dengan sesama manusia dan merusak hubungan dengan diri sendiri. Walaupun demikian, banyak orang percaya tidak memahami tentang dosa dan konsekuensinya.

Jalan keluar dari dosa adalah percaya kepada Yesus Kristus Juruselamat umat manusia. Salib Yesus Kristus adalah lambang kemenangan atas dosa. Dimana salib itu membawa manusia lama yaitu tubuh dosa telah tersalib beserta dengan Yesus. Artinya, semua yang lama telah berlalu dan sekarang telah memiliki hidup yang baru. 


\section{Kepustakaan}

\section{Buku :}

Berkhof, Louis.,

1974 Teologi Sistematika, Edinburgh : Wm. B. Eerdmans Publishing Co

Culver, Robert Duncan., 2006 Systematic Theology: Biblical \& Historical, Germany: Bercker

Diktat Teologi, 2004 Perjanjian Lama, Batu: Institut Injil Indonesia

Foster, Richard J., 1990 Tertib Rohani: Sudahkan Anda Menapakinya?, Malang: Gandum Mas

J, Brill., Tt Dasar Yang Teguh, Cetakan kelima, Bandung, Kalam Hidup Lembaga Alkitab Indonesia, 2007 Mazmur 51:7, Jakarta

MacArthur, John (Ed)., 2003 Think Biblically: Recovery A Christian Worldview, Wheaton, Illinois: Crossway Books

Meeter, H. Henry., 2008 Pandangan-pandangan Dasar Calvinisme, Surabaya: Momentum

Octavianus, P., 1989 Rahasia Kemenangan Atas Dosa, Dep. Literatur YPPII, Batu

Sproul, R.C., 1997 Kebenaran-kebenaran Dasar Iman Kristen, Malang: Seminari Alkitab Asia Tenggara

Williamson, G. I., $1999 \quad$ Katekismus Singkat Westminster, Surabaya: Momentum

Wright, N.T., $2006 \quad$ Evil and the Justice of God, Downers Grove: InterVarsity

\section{Internet}

- http://www.grii-singapore.org/storage-folder/berita-berita-khusus/sin-andlostness/

- http://ekklesiaonnetwork.blogspot.com/2012/12/pandangan-alkitab-tentangkejahatan.html

- http://id.wikipedia.org/wiki/Hukuman

- http://imel-marietta.blogspot.com/2012/08/manusia-menjadi-serigala-bagisesamanya.html

- $\quad$ http://learning.sabda.org/baca.php?b=manusia_dari_penciptaan

- http://obornews.co/4168beritaini_dia_ajaran_sesat_pemicu_bentrok_berdarah di_bireuen. html

- http://www.artikata.com/arti-319794-aspek.html

- http://www.sarapanpagi.org/dosa-definisi-vt294.html

- $\quad$ http://www.sarapanpagi.org/upah-dosa-adalah-mati-vt4419.html

- http://edukasi.kompasiana.com/2012/11/21/gak-percaya-jangan-marah504857.html 